\title{
An Analysis of Ibn-Khaldun's Theory in light of Covid-19 Pandemic
}

\author{
Mohammed Musallem Binham Alameri ${ }^{1}$ and Khawlah M. AL-Tkhayneh ${ }^{2, *}$
}

${ }^{1}$ Former Member of the Federal National Council, Shomokh Study and Researches, Al Ain, UAE

${ }^{2}$ College of Education, Humanities and Social Sciences, Al Ain University, P.O.Box: 64141, Al Ain, UAE

\begin{abstract}
This argumentative paper presents a new perspective on Ibn-khaldun's theory of social change in light of Covid-19. It argues that when examining the theory, it can be found that it makes an association between social change and natural factors, such as epidemics and human factors, such as government changes. The target theory which is explored in this study is the cyclical theory of Ibn-khaldun. This study adopts the former theory in order to analyze the effects of Covid-19 on the Arab-Islamic society, and how this theory was able to predict many of the current events and possible future events using social and historical approaches. The paper consists of four parts as follows: First, an overview of Ibn-khaldun's theory of social change and its philosophy is provided. Second, the role of human factors in social change according to Ibn-khaldun is explored. Third, natural factors affecting social change according to Ibnkhaldun are discussed. Finally, the impact of Covid-19 on our way of life in relation to Ibn-khaldun's theory of social change is examined.
\end{abstract}

Keywords: Ibn-khaldun, theory of social change, Covid-19, human factors, natural factors.

\section{INTRODUCTION}

The pandemic of Covid-19 is considered to be one of the most serious crises that faced humanity and the entire world. The interesting fact that different countries dealt with the pandemic in different ways. Some countries were able to control the spread of the virus and maintain life especially in countries with a strong economy and supportive facilities. Being able to manage the spread of the virus and life maintance does not mean that there were no obstacles or challenges. Many institutions, namely, educational institutions were able to cope with the negative effects of the pandemic reaching for satisfying results. Although there are several negative effects resulting from the pandemic, the precautionary measures applied carried some positive aspects to the extent that many countries are planning to keep applying them even after the end of the pandemic.

The Covid-19 pandemic provides us with a new perception about the way of life in cities in the future. If countries continue applying the same procedures and measures several environmental and security problems would be solved. After the success of the distance working and distance learning experience, the way of life in cities will change. Since people can do their duties without the need to stay cities, many of them are going to move to the countryside. The population density in city will reduce, and consequently the criminal rates and pollution will reduce.

*Address correspondence to this author at the College of Education, Humanities and Social Sciences, Al Ain University, P.O.Box: 64141, Al Ain, UAE; Tel: +971565227651; Fax: +971 3 7024777;

E-mail: khawlah.altkhayneh@aau.ac.ae
Therefore, it was necessary to link between the findings of Ibn-khaldun's theory on social change, on the one hand, and moving to countryside and seeking a simple life style, on the other. The connection would be estasblished in relation to human and natural factors. It should be noted that the social change in the theory does not mean referring to the starting point nor destroying the civilization. Such misconceptions need to be addressed again because Ibn-khaldun stated in different chapters of his book the Muqaddimah that returning to simple life is not always the result of a collapsed state especially in case of a ruler who practices justice. Ibn-khaldun focused on Arab-Islamic societies in his study and he linked the collapse of these societies to the administrative corruption. However, Ibn-khaldun did not refer to any state in particular and did not generalize the results to all societies. In his theory, Ibn-khaldun associated getting back to the first stages of the state's life to certain factors and conditions that will be discussed in this paper. Specifically, the primary aim of this study is to providing answers to the following two questions:

1. What are the natural and human factors affecting the social change according to Ibn-khaldun's theory in light of Covid-19 panademic?

2. To what exten do the procedures applied at the time of Covid-19 panademic affect the way of life in cities, i.e. the social status in the light of Ibnkhaldun's theory of social change?

The significance of the study stems from its role in providing a logical and scientific analysis of Ibnkhaldun's theory. Additionally, it stems from its role in using the theory to explain the current events and 
situation and highlighting the theory's ability to anticipate and predict human crises and dividing them into natural and human. The strength point of this study is its ability to conceptualize the city life after the pandemic using Ibn-khaldun's theory of social change.

\section{DISCUSSION}

\subsection{An Overview of Ibn Khaldun's Theory of Social Change and its Philosophy}

In chapter 17 (section III), Ibn-khaldun (2008) classified his theory of social change into five phases. First, the phase of winning over the enemy and leading the state such beginning would be strong and glorious. Second, the phase of authority and dominance that leads a lot of tribes and people to support the leader. Third, the phase of emptiness due to having a lot of money, buildings and luxuries. In this phase, the country would be at its best level of development and advancement. Fourth, the phase of subservience to the beliefs of the ancestors. Fifth, the phase of the phase of corruption, desires and pleasures if the state moves away from social justice. These phases or stages are part of the cyclical theory (Ibn-khaldun, 2008).

In Chapter 15 (section III), Ibn-khaldun talked about the transition from life of simplicity to life of civilization. It was clearly stated that Bedouin life is the base of any civilized and developed state, i.e. it is considered to be the corner stone civilization (Ibn-khaldun, 2008).

Ibn-khaldun's theory of evolution and social change was classified as one of the 'cyclical theories' that is based on stages of emergence, growth then disappearing at the end in relation to certain conditions. When observing the theory, it can be noticed that the civilization disappears according to two different and interrelated factors: human factors such as the periodic changes of the government and natural factors such as epidemics and diseases.

Ibn-khaldun's thought is not an absolute thought since he belives in the multidemionsional course of Arab-Islamic civilization on the one hand and the rotational change of its governments on the other (Jamshidiha and Ahmad, 2016).

By investigating the topics of Ibn-khaldun's book "Muqaddimah", the aspects of language change can be juistified. It was stated that development or disappearance of a certain civilization is closely related the strength and weakness of the state. Such integration is like a huge spiral facing certain obstacles in its way toward the future due to internal changes happing to the state (Jamshidiha and Ahmad, 2016).

The study of Jamshidiha and Ahmad (2016) opposes all the theories that views Ibn-khaldun's theory as a rotational or decadent theory. It was assured that it is not acceptable to impose the terms "decadence" or "rotational" on a theory that shows both the factors of composition, the factors of competence, power, factors and circumstances of the state's collapse and corruption at the same time.

Ibn-khaldun supported the assumption that practicing injustice is considered to be an important factor in the degradation of any state. Therefore, he suggested a way to prevent the natural degradation of the State which is by practicing juistice. It can be noticed that Ibn-khaldun is trying to say indirectly that for any state to survive and develop, it should rely on the role of juistice (El-Sayed, 1997).

Okene and Ahmad (2011) conducted a study that is viewed to be a great example on Ibn-khaldun's theory of the states's emergence and fall by approaching Sokoto Caliphate in Nigeria, in the early $19^{\text {th }}$ century. In 1801, this country was established based on capabilities such as knowledge, ability and dominance. After that, it reached to the ultimate level of its strength due to economic justice, the prosperity of free trade and the industrial development. However, soon after that it started to fall apart for not adhering to the principles of justice and moving away from its ideological foundation.

Ibn-khaldun differentiated between two factors causing the social changes. First, factors that have an influential role on change and civilizational development. Such factors are described to be the civilization creaters since thay are considered to be the triggers of change. The natural environment, the life style and loyalty to the state are examples on these factors. Second, the factors that prepare and pave the way of change such as juistice, obedience to the leader, industry, wealth and population. All of these play major role in the process of development and innovation (Ibn-khaldun, 2008).

Jamshidiha and Ahmad (2016) assured that Ibnkhaldun is against the idea of unilateral factor behind social change, but he prefers to explain the change through a set of factors working together simultaneously. However, it was stated that these factors vary in their impact and their degree of 
significance depending on the environment in which the factors play their roles. Through dealing with the situation as mentioned, he is explaining the changes that occur to any society in a systematic and relative way.

\subsection{The Role of Human Factors in the Social Change According to Ibn-Khaldun}

In chapter 15, Ibn-khaldun suggested a fundamental idea in relation to civilization in which he views it as a stage in the social, economical and cultural development. In addition to its role in the creation and development of the state. The emergence of the state is moving from bedouin life to urban life, i.e. from a certain social, economic and cultural situation to a more prestigious one (Ibn-khaldun, 2008).

If the emergence of the state is considered as a major factor of the cultural development, so alasabiyyah which means the loyalty and belonging to the state is a major factor in the development of the state. The reason behind such assumption is that the construction of large buildings requires the existence of capitals and manpower. Since alassabiyah and capital are the reason behind the emergence of any state, the absence of them is the reason behind the fall of the state. There is a strong relationship between the state and the alassabiyah of its people since the alassabiyah is the reason behind the establishment of the state (Ibn-khaldun, 2008).

Ibn Khaldun had certain assumptions in relation to the decline of the state in general and the civilization in particular. He suggested that alassabiyah in one hand and economy on the other are the corner stones for the establishment and development of the state. According to him, the tyranny of rulers has a major role in weakening the alassabiyah and the state as well.

In chapter 18 (section VI), Ibn-khaldun mentioned that the increase in population density in a certain state plays a major role in its emergance and development. Such premise can be justified in relation to the fact that the population was viewed as the capital for the increase in the state's productivity due to their efforts in producing art and economy (Ibn-khaldun, 2008).

In Ibn-khaldun's theory, asabiyah is connected in a way or another with the concept of urbanization since it has a role in the rise or the fall of certain states and then the rise and fall of others. There are a lot of obstacles that face alassabiyah such as problems between the members within the same group, debauchery, criminality and much more social, internal and external problems. It was suggested that if all these obstacles were addressed, alassabiyah can be the key for all the nation's distress (Halim, Ibrahim and Hamid, 2012).

Affandi and Astuti (2014) conducted a study to test the challenges that might face the application of the Ibn-khaldun model of social change. In their study, the researchers tried to examine the poverty rates in Indonesia, Malaysia and Pakistan in which the majority of the Muslim population can be found, and India as a minority of the Muslim population. According to Ibnkhaldun's dynamic model of poverty, the poverty is not only influenced by the economical factors, but other factors such as the nation's wealth, government, human resources, growth and justice. The study came up with secondary data about the situation after the financial crisis in 1997 in general or the period between 2000-2010 in particular. It was found that the dynamic model of Ibn-khaldun has a significant effect on the poverty level in Indonesia, but it does not play a major role when applied in Pakistan in which the factor of human development has the largest impact, but its weak role when applied in India. As a result, the application of the Ibn-khaldun's model varies from one country to another. (El-Sayed, 1990)

Gibb (1933) argued that the government policy and population may affect poverty. As a result, applying Ibn-khaldun model would vary accordingly. Chapra (2008) declared that Ibn-khaldun's dynamic and multibranching theory of the development argues that the prosperity or degradation of the society's economy does not depend on one factor, but on the integration of a group of factors such as of moral, social, economical, political and historical factors over a long period of time. One of these factors works as the activation system for the other factors. In case that they act in the same direction and way, the process of development or degradation would be faster. Such theory can be applied on the Islamic countries to explain their poor performance.

\subsection{Natural Factors Affecting Social Change According to Ibn-Khaldun}

In chapter 50 , section III, Ibn-khaldun clamied that at the beginning of its creation, the state must be kind and moderate in its judgment. The more merciful the leader is, the more hopeful and active the citizens are. Accordingly, the construction of buildings and the reprouduction of children would increase. If such 
process developed in a gradual manner, it would affect at least the following two generations. At the end of the two generations, the state will reach the end of its natural age. At this stage, the urbanization would be at its best level of development. Soon after that, corruption and injustice increase leading to famines and death. The reasons behind the increase in famines are as follows. First, farmers stop working on their lands due to the huge taxes imposed on them. Second, it is known that the avalibaility of plants depends on the amount of rainfall in the country and since levels of rainfall differ from one country to another, people are expected to save food for the future time. In case that people do not save food, they would be shocked with the high prices of the plants in times of famines and they would not be able to pay for such products and would die at the end (Ibn-khaldun, 2008).

In relation to the reasons behind the increase in the rates of death, it was proved that in case of corrupted country, the killing would increase. Furthermore, when urbanization increase, air pollution will increase leading to lung diseases. That is why, there is a need to leave spaces between buildings in the city in order to enable the air to move freely getting rid of all the rottenness in it. That is why and according to certain statistics, death rates are more in cities that include large number of buildings. (Ibn-khaldun, 2008)

There is a link between the design of the city and the amount of pollution in it. For example, the design of the Chinese city, Wuhan, where the virus of Covid-19 appeared for the first time, assured such relationship. Wuhan is a very crowded city with no space between the buildings and due to its polluted air the virus managed to spread all over the city and then to the whole world. This can prove Ibn-khaldun's special abilities and his insight into the future since the design of cities described by him in his book is similar to the design of Wuhan city, the source of Covid-19, as suggested by WHO. According to WHO reports, Covid19 is linked to the seafood market in Wuhan since the first group of cases reported on $31^{\text {st }}$ December 2019 were from there (WHO, 2020).

According to the information given to $\mathrm{WHO}$ on $11^{\text {th }}$ and $12^{\text {th }}$ January 2020 by the Chinese authorities, it was stated that there were 41 Covid-19 cases. The preliminary epidemiological investigation shows that the majority of them are either working or buying food from there. It is worth telling that at that time, no cases of Covid-19 were reported anywhere else other than Wuhan (WHO, 2020).
Cheng and Zhou (2015) investigated the accuracy of Ibn-khaldun's theory in relation to the relationship between urban planning and the spread of epidemics and diseases. The findings support the theory since it was found that over the past six decades, the city has undergone dramatic changes at the national and local levels and has witnessed rapid spatial and temporal growth. Such conclusions are expected to explain many economic and social processes facing the world.

By establishing the beginning of metro system in 2000, Wuhan has entered a new era of economic prosperity. Such a thing is a sign of rapid urban development which solved a lot of challenges facing the local urban planning, but it was found to be insufficient and not enough for a comprehensive and integrated planning in Wuhan. Such conclusion was reached to after reviewing the process of urban growth, assessing the roles of urban planning and analysing the obstacles facing them such as transportation issues, population ageing, migration, and the environment.

Cheng and Zhou (2015) suggested that the population density has a major role in spreading the infectious diseases. They proved such assumption by referring to the most densely populated residential complex in the world found in Hong Kong which was the epicentre of the acute respiratory syndrome epidemic in 2002 and 2003. A recent example can support this study is Covid-19 that appeared for the first time in Wuhan which is the most densely populated city in central China. Furthermore, New York city that was the most affected city in the USA since it is the most polluted one.

Green spaces contribute to improving people's physical and psychological health during pandemics. Recognising the importance of green spaces, Poland banned cars from entering the parks allowing citizens to leave their homes during quarantine (Abu Ghanima, 2020). Such findings were expected by Ibn-khaldun in his theory when he talked about the increase in death and famines in time of epidemics and diseases resulting from the increase in urban planning that pollutes the air the animals and human breathe (Ibnkhaldun, 2008).

Acemoglu, Johnson and Robinson (2002) designed a study on the effects of the climate changes on development. They found that the tempreture has a major impact on the development process. Quetelet (1831) explained the relationship between the climate 
and the agricultural productivity, mortality, cognitive performance, crime and social disorders. Quetelet (ibid) refered to it as the geographical school for explaining deviation and abanding values.

Dell, Jones and Olken (2008) found that high temperature has a significant negative effects on the economic growth of both poor and rich countries. In relation to the effect of the high tempreture on the economny of poor countries, it was found that this effect is due to its influence on the growth rates. Furthermore, it was suggested that temperature affects the agricultural and industrial productivity and the investment process in general. Additionally, it was documented that poor countries publish fewer research papers in years of high tempreture indicating that high tempretures may hinder creativity as well. Lastly, it was found that high temperatures lead to political instability in poor countries. Such instability appears in the constant changes of the national leaders.

\subsection{City Life after the Pandemic of Covid-19 Pandemic in Relation to Ibn-Khaldun's Theory of Social Change}

With regard to living in cities and its environmental and security issues, the pandemic of Covid-19 has changed our vision toward city life in the future. If the same procedures used at the time of the pandemic would still be used, life in the future would change a lot. The online teaching and working experience was proved to be successful especially in countries that have powerful economy. This will drive many people to move into the countryside if they do not need to live in city for work or study. If this will be the case, the city would turn into a place with less crime rates, less environmental pollution, less population density and less noise.

Therefore, it was necessary to link between the findings of Ibn-Khaldun's theory on social change, on the one hand, and moving to countryside and choosing a simple life style, on the other. The connection would be established in relation to human and natural factors. It should be noted that the social change in the theory does not mean referring to the starting point nor destroying the civilization. Such misconceptions need to be addressed again, since he mentioned, in different parts of his introduction, that returning to simple life is not always the result of a collapsed state especially in case of a ruler who practices justice, follows the social policies that would maintain the social balance and stays away from corruption and Anomie (AL-Tkhayneh, Alhajjaj and Daher, 2020).
A group of economists, academics and policymakers around the world are convinced that the pandemic of Covid-19 is a great opportunity to reform the economy, environment and lifestyle in the long run.

Many researchers (e.g, Aknick, 2019) have discussed social gaps and spatial injustice found in modern cities. In his article, Park addressed two concepts which are the ethical sphere and the natural Sphere and viewed them as two arbitrary spheres that have no relation with the strategies and policies followed by the government (Aknick, 2019).

One of the most important facts that emerged after the current crisis is that urban planning is not only related to the materialism of the city and its components, but its people ability to participate in its production process. It is the architecture's responsibility to involve the members of a certain society into the production process by suggesting designs for their own buildings and houses. It seems necessary to move to the era of small and cohesive communities instead of big and globalized cities. This need is due to the fact that urbanization, particularly in large cities, has enormous negative effects such as traffic, pollution, waste accumulation and consumption (Murray and Warwick, 2013).

The current crisis invited urban planners to find creative ways to provide poor communities and informal settlements with the appropriate infrastructures making sure their citizens are the main victims of the virus. This requires a significant change in the priorities of urban planning and development. Furthermore, the implementation of policies to improve public health throughout the formal and informal parts of the city is needed (Abu Ghanima, 2020).

In his blog The Post-Corona City, Abu Ghanima (2020) posted the following question: Would public squares become virtual? He stated that public squares are the most expressive places for the idea of community and communication. Meanwhile, at the time of Covid-19, they are not able to play the same role as a mean of communication. Furthermore, he expressed his fear of the social media means such as WhatsApp, Facebook, Twitter, Instagram and others in making the communication process possible without going to squares, cafés or gardens. However, human beings would prefer face to face communication in public squares to communicating online (Abu Ghanima, 2020). 
Kimmelman (2020) declared that cities are the base of capitals and creativity since it is primarily designed to be occupied with large number of people. Furthermore, he stated that epidemics are anti-urban, preying on our human desire to communicate.

\section{CONCLUSION AND RECOMMENDATIONS}

When observing the theory carefully, social change is driven by natural factors such as epidemics, diseases and human factors such as periodic changes of government. These factors are part of a more general theory which is the cyclical theory of Ibnkhaldun. The theory is able to explain and predict many of the current and future events using logical arguments and analysis. Returning to the life of simplicity in the countryside is an expected outcome after the outbreak of Covid-19. This was expected by Ibn-khaldun in his theory of social change. A group of economists, academics and policymakers around the world believe that the epidemic of Covid-19 is an opportunity to reform the economy, environment and lifestyle on the long run. They made such assumption after the success of online learning and working in some of the developed countries such as China, the UAE, America, Britain and others that have strong infrastructures. Urbanization, particularly in large cities, has many drawbacks such as overcrowded public transport, pollution, waste accumulation and spread of the culture of consumption. Moreover, the social and spatial differences which make the access to urban services extremely difficult and exclusive for a small group of lucky people. Accordingly, the study recommends taking into account the results of the study in planning the design of the new city that would appear after the pandemic of Covid-19. The pandemic brought many advagates to the cities such as decreasing the population density, the pollution and the crime rates since many people would move from city to countryside. This was stated in Ibn-khaldun's theory long time ago. Again and again, the study keeps drawing our attention to Ibn-khaldun's forward-looking vision. For instance, the occurrence of the current pandemic was expected by Ibn-khaldun when he talked about the negative effects of the polluted air on health espically in areas with large number of buildings. When the air is strongly polluted, the lungs will be affected directly. All of these are the result of urbanization in cities that lack proper urban planning. This proves the importance of urban planning in protecting against epidemics and diseases. After Covid-19 pandemic, people would prefer to live a simple life in the countryside and accordingly the population density in cities will decrease and consequently the epidemics and disease will reduce.

\section{REFERENCES}

Abu Ghanima, A. 2020. The post-corona city: housing and public spaces. Blogs.

Acemoglu, D., Johnson, S, and Robinson, J. A. 2002. "Reversal of fortune: Geography and institutions in the making of the modern world income distribution". The Quarterly journal of economics 117(4): 1231-1294. https://doi.org/10.1162/003355302320935025

Affandi, A, and Astuti, D. P. 2014. "Dynamic model of Ibn Khaldun theory on poverty: Empirical analysis on poverty in majority and minority Muslim populations after the financial crisis". Humanomics 30(2), 136-161. https://doi.org/10.1108/H-05-2012-0010

Aknick, F. 2019. Robert Park's Ecological Approach. Al-Muthaqaf newspaper is an electronic newspaper issued by the Arab Intellectual Foundation. Issue: 4685 coincidentally.

AL-Tkhayneh, K. M; Alhajjaj, H. A; and Daher, A. 2020. "The Role of Qualitative Social Policies in Achieving the Highest International Indicators of Balance and Social Organization". Humanities \& Social Sciences Reviews 8(2): 352-363. https://doi.org/10.18510/hssr.2020.8240

Chapra, M. U. 2008. "Ibn Khaldun's theory of development: Does it help explain the low performance of the present-day Muslim world?". The Journal of Socio-Economics 37(2): 836-863. https://doi.org/10.1016/j.socec.2006.12.051

Cheng, J., \& Zhou, J. 2015. Urban growth in a rapidly urbanized mega city: Wuhan. In Urban Development Challenges, Risks and Resilience in Asian Mega Cities (pp. 301-322). Springer, Tokyo.

https://doi.org/10.1007/978-4-431-55043-3 16

Dell, M., Jones, B. F., \& Olken, B. A. 2008. "Climate shocks and economic growth: Evidence from the last half century". Nber working paper 14132 . https://doi.org/10.3386/w14132

El-Sayed, Abd., (1990), Urban Sociology. A theoretical introduction, Part One, University Knowledge House Alexandria.

El-Sayed, Abd. 1997. Urban Sociology. Between Theory and Practice, Part Two, University Knowledge House, Alexandria.

Gibb, H. A. 1933. "The Islamic background of Ibn Khaldūn's political theory". Bulletin of the School of Oriental and African Studies 7(1): 23-31. https://doi.org/10.1017/S0041977X00105361

Halim, A. A., Nor, M. R. M., Ibrahim, A. Z. B, and Hamid, F. A. F. A. 2012. "Ibn Khaldun's Theory of 'Asabiyyah and its application in modern Muslim society". Middle-East Journal of Scientific Research 11(9): 1232-1237. https://www.who.int/csr/don/12january-2020-novel-coronavirus-china/ar

Ibn-khaldun, Abd. 2008. Muqaddimah,Beirut: Darolketab Al-Arabi Publication.

Jamshidiha, G, and Ahmad, M. A. 2016. "A new view on Ibn-khaldun, $s$ social change idea". International Journal of Humanitites 22(2).

Kimmelman, M. 2020. "Can City Life Survive Coronavirus?". The New York Times 22.

Murray and Warwick, (2013). Geography of Globalization: A Reading in the Challenges of Economic, Political and Cultural Globalization, translated by Saeed Muntaq, A World of Knowledge Series, No. 397, February 2013, Kuwait, p. 139. 
Okene, A. A, and Ahmad, S. B. 2011. "Ibn Khaldun, Cyclical Theory and the Rise and Fall of Sokoto Caliphate, Nigeria West Africa". International Journal of Business and Social Science 2(4).
Quetelet, A. 1831. Research on the propensity to crime of different ages Brussels: Hayez.

World Health Organization. 2020. emerging corona virus - China.

Received on 03-12-2020

Accepted on 31-12-2020

Published on 18-01-2021

DOI: https://doi.org/10.6000/1929-4409.2021.10.03

(c) 2021 Alameri and AL-Tkhayneh; Licensee Lifescience Global.

This is an open access article licensed under the terms of the Creative Commons Attribution Non-Commercial License (http://creativecommons.org/licenses/by-nc/3.0/) which permits unrestricted, non-commercial use, distribution and reproduction in any medium, provided the work is properly cited. 